Bernard A. MacLeod MD FRCPC, Roy McGroarty BSc, Roy H. Morton MD, Michael J. A. Walker PhD

\title{
Effects of halothane on arrhythmias induced by myocardial ischaemia
}

The effect of halothane on arrhythmias induced by ischaemia was investigated in rats, isolated perfused rat hearts, and pigs. Responses to the occlusion of the left anterior descending coronary artery were determined in groups $(n=9)$ of chronically prepared rats treated with no halothane, 0.5 , or 1.0 per cent halothane immediately after occlusion; in isolated rat hearts $(n=10)$ treated with no halothane, $0.5,1.0,2.0$, or 4.0 per cent halothane for $15 \mathrm{~min}$ before and after occlusion; and $20-25 \mathrm{~kg}$ pigs $(n=11)$ anaesthetised with halothane or pentobarbital. The ECG, arrhythmias, blood pressure (BP), heart rate (HR) and extent of infarction were determined in each model. In pigs, left ventricular pressure, dp/d $t_{\text {max }}$ and cardiac output were also measured. In chronically prepared rats, halothane anaesthesia started after occlusion was antiarrhythmic and decreased the incidence of ventricular fibrillation and resulting mortality. In isolated rat hearts. 0.5 or 1.0 per cent halothane had little effect on occlusion-induced arrhythmias. The highest concentration of halothane increased the incidence of ventricular fibrillation both before and after occlusion. Halothane decreased developed ventricular pressure in a dose-dependent manner. In acutely prepared pigs, halothane pre-treatment had no appreciable effect upon occlusion-induced arrhythmias when compared with pentobarbital anaesthesia. Thus, halothane is antiarrhythmic when treatment is initiated after occlusion in the rat but this action is not seen in isolated hearts or intact pigs. The antiarrhythmic action of halothane is, therefore, species and model dependent.

\section{Key words}

ANAESTHETICS, VOLATILE: halothane; COMPLICATIONS: arrhythmia; HEART: arrhythmias, aetiology, coronary occlusion.

From the Department of Anaesthesiology and Pharmacology \& Therapeutics, Faculty of Medicine, The University of British Columbia, Vancouver.

Supported by the British Columbia Heart Foundation. Address correspondence to: Dr. M.J.A. Walker, Department of Pharmacology \& Therapeutics, The University of British Columbia, 2176 Health Sciences Mall, Vancouver, B.C., V6T 1 W5.
This laboratory has previously reported that halothane anaesthesia diminished ischaemia-induced arrhythmias when compared with pentobarbital anaesthesia. ${ }^{1,2}$ Subsequently we showed that ischaemia-induced arrhythmias were also reduced in incidence, severity, and duration by halothane when compared with conscious rats or rats receiving fentanyl anaesthesia. ${ }^{3}$ This antiarrhythmic action of halothane was dose-dependent, and was much greater than other halogenated anaesthetics (methoxyflurane, enflurane, isoflurane, chloroform) thus demonstrating that halothane reduced severe arthythmias independently of the anaesthetic state. ${ }^{4}$ Other workers have demonstrated that halothane has antiarrhythmic actions against ischaemic arrhythmias in dogs. ${ }^{5.6}$ However, the mechanism of halothane's antiarrhythmic action in rats and dogs remains unknown and the clinical significance of the findings uncertain. $4,6,7$

To investigate the mechanism of action and the clinical relevance of the antiarrhythmic actions of halothane, we addressed the following questions.

(1) Does halothane have antiarrhythmic actions when administered after coronary artery occlusion? If so, similar compounds should be investigated as a possible treatment for ischaemic arrhythmias, independent of their anaesthetic actions, and to provide clues into the mechanism of arrhythmogenesis. The time of onset of the antiarrhythmic action also helps to determine if the drug is acting in the perfused, non-perfused or border regions of the ischaemic zone.

(2) Does halothane have antiarrhythmic actions in isolated perfused hearts? Answers to this question help define mechanisms of antiarrhythmic action, i.e., does it involve direct mechanisms, or indirect ones mediated by the CNS, endocrine or cardiovascular systems.

(3) Is the antiarrhythmic action species dependent? By testing for antiarrhythmic actions in the pig, a species with a similar cardiovascular system to man, the experimental findings can be better extrapolated to man. ${ }^{23}$

\section{Methods}

Study 1 Post-occlusion halothane in chronically prepared rats

Under halothane anaesthesia rats were prepared with a left 
anterior descending coronary artery occluder, an aortic cannula, and ECG leads. ${ }^{4,8}$ Seven days later, the artery was occluded while blood pressure and ECG were recorded. Rats with electrocardiograms showing arrhythmias, myocardial ischaemia or infarction as a result of surgery were discarded. The remaining rats were randomly assigned to receive one of three treatments groups: no halothane, 0.5 , or 1.0 per cent halothane in 100 per cent oxygen. Each treatment group contained nine rats. The coronary artery was occluded after a 30 min stabilization period and the rat was placed immediately in a chamber equilibrated with the assigned halothane concentration administered through a Drager vaporizer and confirmed by a Beckman LB-2 infra-red halothane analyzer. Rats were left in the chamber for $4 \mathrm{~h}$ after occlusion and monitored throughout. The hearts of rats which died in this 4-h period were excised and perfused with cardiac green dye at $100 \mathrm{mmHg}$ pressure in order to determine the extent of the occluded zone (OZ) i.e., that area not stained with dye. Rats surviving $24 \mathrm{~h}$ were subjected to a further 30 -min recording before they were killed and occluded zones determined. Perfused hearts were then sliced and incubated in tetrazolium to determine the infarcted zone. ${ }^{9}$ All arrhythmias were recorded for $4 \mathrm{~h}$ post-occlusion as were BP, HR and ECG. Arrhythmias were recorded as premature ventricular contractions (PVC), ventricular tachycardia (VT), ventricular fibrillation (VF) and summarized as an anthythmia score based on the type, duration, and severity of a rat's arrhythmia history. ${ }^{8}$ The number of PVCs was expressed as $\log _{10}$ since our previous studies have shown that this transform results in normally distributed data suitable for parametric analysis. ${ }^{8}$ Similarly the arrhythmia score was chosen to result in a normally distributed value for use in parametric statistics.

\section{Study 2 Isolated rat hearts}

Hearts were removed from Sprague-Dawley rats and perfused with Krebs-Henseleit solution equilibrated with five per cent carbon dioxide in oxygen by means of the Langendorff technique. ${ }^{10,12}$ An occluder was placed around the left anterior descending coronary artery. ${ }^{11}$ Ventricular pressure was measured with a compliant ventricular balloon and the ECG recorded from the surface of the heart using silver/silver chloride electrodes. ${ }^{12}$ Halothane-free perfusate was used for $30 \mathrm{~min}$ before switching to a perfusate equilibrated with either no halothane, $0.5,1.0,2.0$, or 4.0 per cent halothane in the above gas. After $15 \mathrm{~min}$ of perfusion with the halothanecontaining solution, the preocclusion period was started. The ECG, ventricular pressure and perfusate flow were monitored for this 30 -min period and for $30 \mathrm{~min}$ after occlusion.

Halothane concentrations were set in a manner blinded to the experimenter and ten hearts were randomly assigned to each treatment group. The occluded zone was determined as in intact rats.

Study 3 Acutely prepared pigs

Twenty-two $20-25 \mathrm{~kg}$ castrated male Yorkshire piglets were randomly assigned to two groups; one anaesthetized with pentobarbital $30 \mathrm{mg} \cdot \mathrm{kg}^{-1}$ intraperitoneally followed by $2 \mathrm{mg} \cdot \mathrm{kg}^{-1}$ IV boluses as required, the other anaesthetized with $1-1.25$ per cent halothane. The tracheas were intubated and the lungs ventilated with oxygen at 10 $\mathrm{ml} \cdot \mathrm{kg}^{-1}, 10-12$ times per min. Arterial blood gases were determined using a Radiometer blood gas analyzer and end-tidal carbon dioxide with a Beckman LB-2 infra-red analyzer. The heart was exposed via a thoracotomy, 4th intercostal space, and suspended in a pericardial sling. A 3-0 polyethylene suture was inserted through the heart beneath the left anterior descending artery immediately proximal to the first diagonal branch and passed through a polyethylene tube so as to form a snare, as in the rat heart, which was brought out through the chest wall.

A 7F Edwards thermodilution Swan-Ganz catheter was inserted through an apical stab wound. The proximal port was used to monitor the left ventricular pressure, and $\mathrm{dp} / \mathrm{dt}_{\max }$, and the distal port was used to monitor aortic pressure. Leads II and V-3 of the EGG were monitored. The chest was closed and the pigs were left for $30 \mathrm{~min}$ to stabilize before occluding the artery by tightening the snare. Observations were continued for $6 \mathrm{~h}$ after occlusion and arrhythmias, ECG, BP, dp/dt $t_{\max }$, heart rate, endtidal $\mathrm{CO}_{2}$, and cardiac output were monitored. Episodes of ventricular fibrillation were cardioverted with a DC defibrillator whenever possible. At the end of the $6 \mathrm{~h}$ observation period, the hearts were removed and perfused to determine the occluded zone. In a manner analogous to our method in the rat, an arrhythmia score was used to summarise an animal's arrhythmic history. Statistical analysis of parametric data was performed in our normal manner ${ }^{8}$ using ANOVA and Duncan's multiple range tests. This statistical package is valid for repeated measures. Non-parametric data was tested by using contingency tables based upon chi-squared statistics.

\section{Results}

Study 1 Post-occlusion halothane in chronically prepared rats

Halothane started after coronary occlusion was antiarrhythmic over the $4 \mathrm{~h}$ observation period (Table I). The incidence of VF in both the halothane-treated groups was reduced particularly in the 0.5 per cent halothane group ( $P$ $<0.05$ ). There was also a decrease in mortality from four out of nine in controls to one out of nine in the 0.5 per cent 
TABLE I The effect of halothane begun after occlusion on arrhythmias in chronically prepared rats

\begin{tabular}{lllll}
\hline \multirow{3}{*}{$\begin{array}{l}\text { Halothane } \\
(5)\end{array}$} & \multicolumn{3}{l}{ Incidence } & \\
\cline { 3 - 4 } & $\log _{10} P V C$ & $V F$ & $V T$ & $\begin{array}{l}\text { Arrhythmia score } \\
(\bar{x} \pm \text { SEM })\end{array}$ \\
\hline 0.0 & $2.3 \pm 0.2$ & $9 / 9$ & $9 / 9$ & $5.4 \pm 0.6$ \\
0.5 & $1.4 \pm 0.3$ & $0 / 9^{*}$ & $6 / 9$ & $2.3 \pm 0.5^{*}$ \\
1.0 & $1.9 \pm 0.2$ & $6 / 9$ & $8 / 9$ & $4.6 \pm 0.5$ \\
\hline
\end{tabular}

Each group consisted of nine rats. Halothane was administered inmediately after occlusion and continued for $4 \mathrm{~h}$. Arthythmias are reported over this 4 -h period. Premature ventricular contractions (PVC) are expressed as the normally distributed $\log _{10}$ values (see Methods). * Statistical significance, $\mathrm{P}<0.05$ from control (0\% halothane).

group. In this latter group, death resulted from hypotension and not from arrhythmias. As expected, halothane decreased blood pressure and heart rate in a dosedependent fashion (Table II). This cardiovascular depression was reflected in an increase in the number of deaths from non-arrhythmic causes with increasing halothane concentrations.

\section{Study 2 Isolated rat hearts}

Halothane did not reduce the incidence of ischaemiainduced arrhythmias in isolated rat hearts (Table III).In fact, four per cent halothane treatment resulted in ventricular fibrillation before occlusion. Ventricular systolic pressure decreased with increasing halothane concentrations, at four per cent halothane, the developed pressure was only $30-40$ per cent of control values (Table IV). End diastolic pressure was also decreased in a dose-dependent manner. Halothane had no significant effect upon the rate of the spontaneously beating heart. The apparent increased variation in heart rate at higher doses was due to the tachyarrhythmias induced by halothane.
TABLE III Effect of halothane begun before occlusion upon arthythmias in isolated perfused rat hearts

\begin{tabular}{|c|c|c|c|c|c|}
\hline \multirow{3}{*}{$\begin{array}{l}\text { Halothane } \\
\text { (\%) }\end{array}$} & \multirow[b]{3}{*}{$\log _{10} P V C$} & \multicolumn{4}{|c|}{ Incidence of major arrhythmias } \\
\hline & & \multicolumn{2}{|l|}{$V T$} & \multicolumn{2}{|l|}{$V F$} \\
\hline & & pre & post & pre & post \\
\hline 0.0 & $1.1 \pm 0.2$ & 0 & 2 & 0 & 0 \\
\hline 0.5 & $1.0 \pm 0.3$ & 0 & 5 & 0 & 0 \\
\hline 1.0 & $1.2 \pm 0.3$ & 0 & 5 & 0 & 0 \\
\hline 2.0 & $1.7 \pm 0.2$ & 2 & $7^{*}$ & 1 & 2 \\
\hline 4.0 & $0.7 \pm 0.3$ & 2 & 2 & 7 & $5^{*}$ \\
\hline
\end{tabular}

The table shows the incidence of ventricular tachycardia (VT) and ventricular fibrilation (VF) occurring in the 30 -min periods before and after occlusion of the LAD coronary artery,

$\log _{10}$ values are given as mean $\pm S E M$ of the post-occlusion values minus the pre-occlusion values.

The number of hearts in each group was 10 .

Haiothane, in $95 \% \mathrm{O}_{2}$ plus $5 \% \mathrm{O}_{2}$ was bubbled through perfusate at the \% concentration indicated.

*Statistical significance, $\mathrm{P}<0.05$ from control ( $0 \%$ halothane).

\section{Study 3 Acutely prepared pigs}

As shown in Table $\mathrm{V}$, halothane did not decrease the incidence of ischaemia-induced arrhythmias in acutely prepared pigs when compared with pentobarbital. Neither arrhythmia score, nor the overall incidence of VT or VF was decreased. The incidence of VF in the late arrhythmic period ( 45 min- $6 \mathrm{~h}$ ) was reduced; however, this antiarrhythmic effect was nullified by an increased incidence of VF in the early period ( $0-45 \mathrm{~min}$ ). The incidence of PVC in the late period was slightly decreased. Blood pressure and heart rate in the pigs treated with halothane were $10 w^{13}$ (Table VI). The cardiac output post-occlusion was slightly higher in the halothane group, while the $\mathrm{dp} / \mathrm{dt}_{\max }$ was not significantly changed. The occluded zone size was the same for the two groups.

TABLE II The effect of halothane begun after occlusion on mortality, occluded and infarcted zones, HR and BP in the rat

\begin{tabular}{|c|c|c|c|c|c|c|}
\hline \multirow{2}{*}{$\begin{array}{l}\text { Halothane } \\
(\%)\end{array}$} & \multicolumn{2}{|c|}{ \% Ventricular wt } & \multicolumn{2}{|c|}{ Mortality } & \multicolumn{2}{|c|}{ Cardiovascular variables } \\
\hline & $O Z$ & $I Z$ & $a r r$ & non-arr & $B P(m m H g)$ & $H R$ (beats $\cdot$ min $^{-1}$ ) \\
\hline 0.0 & $36 \pm 1$ & 36 & $4 / 9$ & $0 / 9$ & $104 \pm 3$ & $377 \pm 21$ \\
\hline 0.5 & $34 \pm 1 *$ & 30 & $0 / 9$ & $1 / 9$ & $81 \pm 7^{*}$ & $374 \pm 11$ \\
\hline 1.0 & $39 \pm 1$ & 35 & $1 / 9$ & $3 / 9$ & $63 \pm 5^{*}$ & $339 \pm 7^{*}$ \\
\hline
\end{tabular}

Values are expressed as $\bar{x} \pm$ SEM where $n>5$. For mottality, the number of deaths is expressed as a fraction of the group total.

Arr-refers to death resulting directly from an arrhythmia.

Non-arr-indicates death from causes other than arrhythmias.

$O Z$ and IZ refer to occluded and infarcted zones as determined by dye occlusion and tetrazolium staining, respectively.

BP and HR are those recorded $30 \mathrm{~min}$ after occlusion

* Statistical significance, $\mathrm{P}<0.05$ from control ( $0 \%$ halothane). 
TABLE IV Cardiovascular effects of halothane on isolated perfused rat hearts

\begin{tabular}{|c|c|c|c|c|c|c|c|}
\hline \multirow[b]{3}{*}{$\begin{array}{l}\text { Halothane } \\
\text { (\%) }\end{array}$} & \multicolumn{3}{|c|}{ Ventricular pressures } & & & & \\
\hline & \multicolumn{2}{|l|}{ Systolic } & \multirow{2}{*}{$\begin{array}{l}\text { Diastolic } \\
+30 \mathrm{~min}\end{array}$} & \multicolumn{2}{|l|}{ Heart rate } & \multicolumn{2}{|c|}{ Coronary flow } \\
\hline & $-1 \min$ & $\begin{array}{l}+30 \mathrm{~min} \\
(\mathrm{mmHg})\end{array}$ & & $-1 \mathrm{~min}$ & $\begin{array}{l}+30 \mathrm{~min} \\
\left.?^{-1}\right)\end{array}$ & $-3 \min$ & $\begin{array}{l}+30 \mathrm{~min} \\
-i)\end{array}$ \\
\hline 0.0 & $125 \pm 14$ & $98 \pm 12$ & $28 \pm 4$ & $240 \pm 20$ & $230 \pm 20$ & $125 \pm 10$ & $90 \pm 15$ \\
\hline 0.5 & $123 \pm 11$ & $90 \pm 8$ & $26 \pm 4$ & $230 \pm 10$ & $210 \pm 10$ & $115 \pm 10$ & $85 \pm 15$ \\
\hline 1.0 & $115 \pm 10$ & $85 \pm 7$ & $16 \pm 5^{*}$ & $240 \pm 5$ & $200 \pm 20$ & $125 \pm 15$ & $100 \pm 20$ \\
\hline 2.0 & $70 \pm 12^{*}$ & $72 \pm 8^{*}$ & $13 \pm 4^{*}$ & $360 \pm 90$ & $220 \pm 20$ & $115 \pm 15$ & $80 \pm 10$ \\
\hline 4.0 & $48 \pm 16^{*}$ & $44 \pm 9 *$ & $11 \pm 5^{*}$ & $420 \pm 210$ & $180 \pm 20$ & $115 \pm 25$ & $85 \pm 20$ \\
\hline
\end{tabular}

The table summarizes as mean \pm SEM $(n=10)$ ventricular pressures, HR (usually sinus) and coronary flow at 1 min betore and 30 min after occlusion.

In the case of left ventricular diastolic pressures the values for all groups at -1 min were not significantly different from $15 \mathrm{mmH}$ which was the initial pressure set in the intra-ventricular balloon

${ }^{*} \mathrm{P}<0.05$ from control (0\% halothane).

TABLE $V$ The effect of halothane begun before occlusion on arhythmias in acutely prepared pigs

\begin{tabular}{|c|c|c|c|c|c|c|c|c|}
\hline \multirow[b]{2}{*}{ Anaesthetic } & \multicolumn{2}{|c|}{$\log _{10} P V C$} & \multicolumn{2}{|l|}{$V F$} & \multicolumn{2}{|l|}{$V T$} & \multicolumn{2}{|c|}{ Arrhythmia score } \\
\hline & $0-3 / 4 h$ & $3 / 4-6 h$ & $0-3 / 4 h$ & $3 / 4-6 h$ & $0-3 / 4 h$ & $3 / 4-6 h$ & $0-3 / 4 h$ & $3 / 4-6 h$ \\
\hline Halothane & $0.9 \pm 0.2$ & $1.3 \pm 0.1^{*}$ & 4 & 0 & 4 & 5 & $3.7 \pm 0.7$ & $3.1 \pm 0.6$ \\
\hline Pentobarbitone & $0.7 \pm 0.2$ & $1.7 \pm 0.1$ & 3 & 3 & 5 & 7 & $3.3 \pm 0.8$ & $3.6 \pm 0.5$ \\
\hline
\end{tabular}

Arrhythmias were analyzed in the manner used for rats in Table I.

Except for incidence of VF, VT and mortality, all values are mean \pm SEM.

For VF and VT the number of animals in a group $(n=11)$ having one or more episodes of VF or VT is shown.

The time periods are the two arrhythmic periods, $0-3 / 4$ and $3 / 4-6 \mathrm{~h}$ post-acclusion.

${ }^{*} \mathrm{P}<0.05$, for differences from pentabarbitone anaesthesia.

\section{Discussion}

Previously we showed that, in chronically prepared rats, halothane decreased the incidence, severity, and duration of ischaemia induced ventricular arthythmias. This protective effect was dependent upon the concentration of halothane. It was present at subanaesthetic concentration, 0.25 per cent, rose to a peak at 1 per cent and then decreased in importance as the animals died of decreased cardiac output. ${ }^{3,4}$ The present study demonstrated that halothane treatment, initiated after occlusion, prevented ischaemia-induced arrhythmias as effectively as when treatment was begun before occlusion. ${ }^{3,4}$ The differences between the two studies in halothane's efficacy as an antiarrhythmic agent may well reflect the delay in obtaining the desired concentration of halothane in the present study, since it has been shown that 5 min after starting halothane, the alveolar concentration in the rat is half the inspired concentration. ${ }^{14}$ Although the rat heart has no functional collaterals, it cannot be assumed that halothane did not reach significant concentrations in the ischaemic zone since we have found in this model that verapamil given after occlusion gains ready access to the ischaemic zone. ${ }^{15}$
Our investigation of the possible antiarrhythmic actions of halothane in isolated hearts was complicated by a low incidence of VF in such hearts. We feel that this may have been due to our use of $5.9 \mathrm{mEq} \cdot 1^{-1}$ potassium ${ }^{10}$ in the perfusate in order to stabilize the heart. Ischaemic arrhythmias in rat hearts, in vitro and in vivo depend critically upon the potassium concentration in the perfusate or the serum. ${ }^{16.17}$ Nevertheless, not only was there no reduction in ventricular tachycardia or PVCs with halothane, there was an increase in the incidence of VF at the highest concentrations. The pharmacological effectiveness of halothane on the isolated hearts was confirmed by halothane-dependent reductions in ventricular pressure.

The marked difference between the antiarrhythmic actions of halothane in isolated hearts, compared with intact rats, suggests that the antiarrhythmic action of halothane does not involve a direct action on the heart. Therefore, halothane's antiarrhythmic action would not be due to its calcium antagonist actions on myocardial cells as has been suggested. 4,6,7,21,22 Ischaemia-induced arrhythmias may be dependent upon neurological input, ${ }^{18}$ since halothane reduces sympathetic nervous system activity, ${ }^{19}$ this may be responsible for the reduction in 
Table VI The cardiovascular effects of halothane pretreatment in acutely prepared pigs

\begin{tabular}{|c|c|c|c|c|c|c|c|c|}
\hline \multirow[b]{2}{*}{ Anesthetic } & \multirow[b]{2}{*}{ Time } & \multirow[b]{2}{*}{$\% O Z$} & \multirow[b]{2}{*}{ Mortality } & \multicolumn{2}{|c|}{$B P(m m H g)$} & \multirow{2}{*}{$\frac{H R}{B \text { Bear-min } \min ^{-1}}$} & \multirow{2}{*}{$\frac{C O}{L \cdot \min ^{-1}}$} & \multirow{2}{*}{$\frac{d p / d t}{m m H g \cdot \sec ^{-1}}$} \\
\hline & & & & Sys & Dias & & & \\
\hline \multicolumn{9}{|l|}{ Halothane } \\
\hline & $-1 \mathrm{~min}$ & & 0 & $94 \pm 4$ & $54 \pm 4$ & $105 \pm 4$ & $2.8 \pm 0.1$ & $1330 \pm 60$ \\
\hline & $+30 \mathrm{~min}$ & & 3 & $74=7^{*}$ & $46 \pm 5^{*}$ & $123=11$ & $2.4 \pm 0.1^{*}$ & $925 \pm 145^{*}$ \\
\hline & $+4 \mathrm{~h}$ & & 4 & $86 \pm 6^{*}$ & $50 \pm 3^{*}$ & $143=10$ & $2.3 \pm 0.1^{*}$ & $1120 \pm 50^{*}$ \\
\hline & $+6 h$ & $25.5 \pm 1.7$ & 5 & $78 \pm 5^{*}$ & $45 \pm 3^{*}$ & $162 \pm 15$ & $2.4 \pm 0.5$ & $1350 \pm 200$ \\
\hline \multicolumn{9}{|c|}{ Pentobarbitone } \\
\hline & $-1 \min$ & & 0 & $108 \pm 5$ & $68 \pm 3$ & $117 \pm 5$ & $2.5 \pm 0.2$ & $1490 \pm 50$ \\
\hline & $+30 \mathrm{~min}$ & & 2 & $102 \pm 6$ & $69 \pm 5$ & $124 \pm 4$ & $2.0 \pm 0.2$ & $1610 \pm 105$ \\
\hline & $+4 \mathrm{~h}$ & & 4 & $112 \pm 7$ & $76 \pm 7$ & $138 \pm 10$ & $1.8 \pm 0.1$ & $1450 \pm 135$ \\
\hline & $+6 h$ & $25.9 \pm 2.3$ & 4 & $99 \pm 5$ & $60 \pm 4$ & $165=9$ & $2.0=0.2$ & $1575 \pm 100$ \\
\hline
\end{tabular}

Values are given as $\bar{x} \pm$ SEM for groups of 11 pigs. Occluded zone size was deternined after death by dye occlusion.

All other values were calculated for the time periods pre- $(-1 \mathrm{~min})$ and post-occlusion $(30 \mathrm{~min}, 4 \mathrm{~h}$ and $6 \mathrm{~h}$ ).

The accumulated mortality for each time period is recorded.

The occluded zone $(\mathrm{OZ})$ is the percentage of total ventricular weight.

*Statistically significant differences from pentobarbitone anaesthesia, $\mathrm{P}<0.05$.

ischaemic arrhythmias. In the intact rat, however, mechanisms involving adrenergic activity are unlikely since we have previously shown that $\beta$-blockade, $\alpha$-blockade, or sympathectomy, do not decrease the incidence of ischaemic arrhythmias. ${ }^{20}$

Regardless of its mechanism of antiarrhythmic action, it is important to consider the effect of halothane in different animal models since each model may well represent a different aspect of human disease. For example, dog hearts generally have functional collaterals, while pig hearts have none. ${ }^{23}$ Futhermore, the greater the number of species in which an effect can be demonstrated, the greater the chance that the effect can be extrapolated to man. In acutely prepared pigs, halothane produced little or no antiarrhythmic action. Certainly it was much less antiarthythmic than either chronically or acutely prepared rats or dogs. The reasons for this are unclear. In pigs, although halothane reduced blood pressure and heart rate, the incidence of arrhythmias was not reduced. A reduced incidence of arhythmias might be expected if oxygen demand was decreased. It is possible that the blunting of the sympathetic response to surgery and coronary artery occlusion by halothane was different in the pig from the rat under the experimental conditions used. It must also be noted that only one halothane concentration was studied in the pig, unlike the studies in rats and dogs. However, this concentration was within the expected effective range without producing the marked cardiovascular depression associated with death in the rat. The data from the pig was complicated by the use of pentobarbital as a basal anaesthetic. We are satisfied that the chronically prepared rat model does not involve undue discomfort to the rat. Unfortunately any attempt at producing myocardial is- chaemia in the pig was met with such obvious distress that we felt obliged to provide a background anaesthetic.

These studies demonstrate the possibility of both a prophylactic and a therapeutic antiarrhythmic action of halothane against ischaemic arrhythmias in man as well as other animals. The demonstration that this action is species and model specific emphasizes that all such observations in laboratory animals need to be tested in man before clinical decisions can be based upon them. The observations can only serve to guide the choice of further laboratory animal or human experiments.

\section{Acknowledgements}

This research was funded by the B.C. Heart Foundation. We would like to thank Kathleen Saint for her help with the technical aspects of the study.

\section{References}

1 Au TLS, Collins GA, Harvie CJ, Walker MJA. Actions of prostaglandins $I_{2}$ and $E_{2}$ on coronary occlusioninduced arrhythmias in the rat. In: Samuelson B, Ramwell PW, Paoletti R (Eds.). Adv Prostaglandin Thromboxane Research. Vol. 7. New York: Raven Press, 1980.

2 Au TLS, Collins GA, MacLeod BA, Walker MJA. Effects of prostaglandin $E_{2}$, propranolol and nitroglycerine with halothane, pethidine or pentobarbitone anaesthesia on arrhythmias and other responses to ligation of a coronary artery in rats. Br. J. Pharmac 1983; 79; 929-37.

3 MacLeod BA, Augereau P, Walker MJA. Effects of halothane anesthesia compared with fentanyl anesthesia and no anesthesia during coronary ligation in rats. Anesthesiology 1983; \$8: 44-52. 
4 Jang TL, MacLeod BA, Walker MJA. Effects of halogenated hydrocarben anaesthetics on responses to ligation of a coronary artery in chronically prepared rats. Anesthesiology 1983; 59: 309-15.

5 Fukuyama $T$, Marmor A, Roberts $R$. The disparate effects of anesthetics on infarct size and mortality during experimental infarction. Clin Res 1981; 29: 193A.

6 Kroll, DA, Knight $P R$. Antifibrillatory effects of volatile anesthetics in acute occlusion/reperfusion arhythmias. Anesthesiology 1984; 61: 657-61.

7 Lynch, $C$. Are volatile anaesthetics really calcium entry blockers? Anesthesiology 1984; 61: 643-4.

8 Johnston KM, MacLeod BA, Walker MJA. Responses to ligation of a coronary artery in conscious rats and the actions of antiarrhythmics. Can J Physiol Pharmacol 1983; 61: 11, 1340-53.

9 Nachlas MM, Snitka TK. Macroscopic identification of early myocardial infarcts by alteration in dehydrogenase activity. Am J Pathol 1963; 42: 379-405.

10 Broadley $K J$. The Langendorff heart preparationreappraisal of its role as a research and teaching model for coronary vasoactive drugs. J. Phannac Methods 1979; 2: 143-56.

11 Woodward, $B$. A model of ventricular fibrillation in the isolated rat heart. J. Pharmac Methods 1981; 6: 219-31.

12 Curtis MJ, MacLeod BA, Tabrizchi R, Walker MJA. An improved perfusion apparatus for small animal hearts. J Pharmac Methods 1986; 15: 87-94.

13 Merlin RG, Verdouw PD, de Jong JW. Myocardial function and metabolic response to ischaemia in swine during halothane and fentanyl anaesthesia. Anesthesiology 1982; 56: 84-92.

14 Whahrenbrock EA, Eger EI 11, Laravuso RB, Maruschak $G$. Anesthetic uptake. Of mice and men (and whales). Anesthesiology 1973; 39: 19-23.

15 Curtis $M J$, MacLeod BA, Walker MJA. Antiarrhythmic actions of verapamil against ischaemic anthythmias in the rat. Br J Pharmac 1984; 83: 373-85.

16 Curtis MJ, Johnston KM, Walker MJA. Arrhythmias and serum potassium during myocardial ischaemia. IRCS Med Sci 1985; 13: 688-9.

17 Daugherty A, Mohammed OY, Woodward B. Effect of poassium on coronary artery ligation induced ventricuJar arrhythmias in perfused coronary ligated rat hearts. J Physiol (Lond) 1983; 340: 66P.

18 Ebert PA, Vanderbeck RB, Allgood RJ, Sabkiston DC. Effect of chronic cardiac denervation on arrhythmias after coronary artery ligation. Cardiovasc Res 1970; 4: 141-7.

19 Metz $S$, Maze M. Halothane concentration does not alter the threshold for epinephrine-induced arthythmias in dogs. Anesthesiology 1985; 62: 470-4.
20 Botting JH, Johnston KM, MacLeod BA, Walker $M J A$. The effect of modification of sympathetic activity on responses to ligation of a coronary artery in the conscious rat. Br J Pharmac 1983; 79: 265-71

21 Lynch C, Vogel S. Sperelakis N. Halothane depression of myocardial slow action potentials. Anesthesiology 1981; 55: 360-8.

22 Blanck TJJ, Vogel S, Pratila MG, Sperelakis $N$. Calcium transport by cardiac sarcoplasmic reticulum: modulation of halothane action by substrate concentration and $\mathrm{pH}$. Anesth Analg 1981; 60: 390-4.

23 Schaper $W$. Collateral circulation of the heart. Clinical Studies. Vol 1. New York: North Holland Pub Co., American Elsevier Pub. Co. Inc., 1971.

\section{Résumé}

L'effet de l'halothane sur les arythmies induites par une ischémie a été investigué chez des coeurs de rats isolés et perfusés, et chez des cochons. Les réponses à l'occlusion de l'artère coronaire descendante antérieure ont été déterminées chez des groupes $(n=9)$ de rats préparés d' une façon chronique et traites avec 0 halothane, 0.5, ou 1 pour cent d'halothane immédiatement après l'occlusion; chez des coeurs de rats isolés ( $n=10$ ) traités avec 0 halothane, 0.5, 1.0, 2.0 ou 4.0 pour cent d'halothane pour 15 minutes avant et apres l'occlusion; et des cochons de 20-25 kg ( $n=11)$ anesthésiés avec de l' halothane ou du pentobarbital. $L ' E C G$, les arythmies, la rension antérielle $(B P)$, la fréquence cardiaque (HR) et l'exiension de l' infarcius ont été déterminé dans chaque expérience. Chez les cochons, lo pression du ventricule gauche, $d p / d t_{\max }$ et le débit cardiaque ont aussi eté mesurés. Chez les rats préparés de façon chronique, l'anesthésie à l'halothane ayant commencé après l'occlusion était antiarythmique et diminua l'incidence de la fibrillation ventriculaire et de la morralité. Chez les coeurs de rats isolès, $0.5 \mathrm{ou} 1.0$ pour cent d' halothane n'avait aucun effet sur les arythmies induites par l'occlusion. Les concentrations elevées d'halothane ont augmenté l'incidence de fibrillation ventriculaire tant avant qu'après l'occlusion. L'halothane a diminué la pression ventriculaire et cette diminution était proportionnelle à la dose administrée. Chez les cochons préparés d'une façon aiguë, le traitement avec l'halothane n'avait aucun effet appréciable sur les arythmies induites par l'occlusion comparativement l'anesthésie au pentobarbital. Ainsi, l' halothane est antiarythmique si son administration suit l'occlusion chez les rats seulement, mais cette action n'est pas observée chez les coeurs isolés ou les cochons intacts. L'action antiarythmique de l'halothane est ainsi dépendante de l'espèce et du modèle utilise. 